\title{
Exploring strontium titanate as a reforming catalyst for dodecane
}

\author{
K. Hbaieb ${ }^{1,2}$
}

Received: 31 May 2015/Accepted: 25 August 2015/Published online: 9 September 2015

(c) The Author(s) 2015. This article is published with open access at Springerlink.com

\begin{abstract}
Yttrium-doped strontium titanate (YST)-based perovskite has been explored as catalyst for reforming dodecane. Active metal elements such as ruthenium, nickel and cobalt were doped on the B-site of the perovskite to boost the catalyst activity. Commercial Ni-alumina catalyst has been used for benchmarking. Both steam and autothermal reforming schemes have been used at 800 and $850{ }^{\circ} \mathrm{C}$. Irrespective of the doping elements, all catalysts performed well and had comparable activity and conversion as the commercial catalyst with slight advantage for ruthenium followed by nickel-based catalysts. Hydrogen and syngas yields fall into the range of 65-75 and 83-91\%, respectively. Conversion was consistently between 84 and $90 \%$. As such, the YST-based perovskite is a promising catalyst for reforming of heavy liquid hydrocarbon fuel.
\end{abstract}

Keywords Perovskite $\cdot$ Strontium titanate $\cdot$ Catalysis · Reforming $\cdot$ Hydrogen production

\section{Introduction}

Fuel cell as a serious potential alternative to the conventional engine for powering transportation vehicles suffers from lack of fuel flexibility as hydrogen is merely the only

K. Hbaieb

hbaiebkais@gmail.com; khbaieb2002@yahoo.com

1 Strategic Technology Unit, Taibah University, Madinah, Kingdom of Saudi Arabia

2 Department of Mechanical Engineering, College of Engineering, Taibah University, Madinah, Kingdom of Saudi Arabia favorable fuel. However, hydrogen infrastructure, distribution and storage are very complicated and prohibitively expensive. As such, developing an onboard reformer of existing commercial fossil fuel to produce hydrogen is a prominent intermediate solution.

The development of an onboard reformer necessitates the search for an effective reforming catalyst. The traditional Ni-alumina-based catalyst is a well-established catalyst for methane steam reforming. It has been further developed on different fronts. At the one hand, loading promoters and/or active metals such as $\mathrm{Cu}, \mathrm{La}, \mathrm{Cr}, \mathrm{K}, \mathrm{Ca}$, $\mathrm{Mo}, \mathrm{Pd}$ and $\mathrm{Mn}$ on the catalyst support lead to enhanced catalytic reactivity as compared with traditional $\mathrm{Ni} / \mathrm{Al}_{2} \mathrm{O}_{3}$ catalyst (Lee et al. 2004; Martinez et al. 2004; Wang et al. 2003; Juan-Juan et al. 2004; Ayabe et al. 2003; Dias and Assaf 2003; Chen et al. 2004; Quincoces et al. 2002; Zhang et al. 2003; Ho et al. 2002; Wang et al. 2004). On the other hand, replacing alumina support with other supports of higher oxygen ionic conductivity improves resistance to carbon formation (Wang et al. 2004; Nimwattanakul et al. 2006; Matsumura and Nakamori 2004; Guo et al. 2004; Zhu and Flytzani-Stephanopoulos 2001). For example, Descorme (Descorme et al. 2000) have reported that lanthanum gallate doped with non-reducible elements such as gadolinium and samarium has positive impact on the catalyst activity.

Incorporating catalytically active metals in some stable ceramic structures such as perovskite and pyrochlore has been the subject of many research studies. For example, Liu (Liu and Krumpelt 2005) have used different lanthanum chromites as reforming catalysts for diesel. Ruthenium at low concentration levels (5\%) has been incorporated on the B-site of such perovskites. During the reforming process, the near-surface ruthenium pops up to the surface and undergoes reduction. When testing for 
reforming activity, such perovskites have shown unusual reactivity and excellent stability. The catalysts performed well or sometimes even better than the high-cost and highly active rhodium-based catalysts. Many other studies reported similar results using different perovskite-based catalyst doped with active metals on the B-site (Mota et al. 2012; Villoria et al. 2012; Provendier et al. 2001; Erria et al. 2006; Dinka and Mukasyan 2007; Mawdsley and Krause 2006; Dinka and Mukasyan 2007). The common factor in all of these catalysts is the well dispersion of the active metals and their reduction at the surface during the reforming process.

Yttrium strontium titanate-based perovskite has shown excellent performance when used as anode for solid oxide fuel cell. This is mainly attributed to the mixed ionic conductivity that such material has at high temperature. Fergus (Fergus 2006) has measured the ionic conductivity of strontium titanate perovskite after doping the A-site at different doping elements namely $\mathrm{Y}, \mathrm{Nb}, \mathrm{Sm}$ and $\mathrm{Eu}$ at different dopant concentrations. In all cases, A-site deficiency is created. Among the various oxides analyzed, the highest conductivity was for $\mathrm{Y}_{0.08} \mathrm{Sr}_{0.88} \mathrm{TiO}_{3}$. This material is chosen for our analysis. Further doping at the B-site can be conducted with different active metals (Kondakindi et al. 2010; Dinka and Mukasyan 2007; Navarro et al. 2007; Mawdsley and Krause 2008). Such further doping is meant to improve the activity of the material. The prepared catalysts were benchmarked against $\mathrm{Ni}$-alumina catalyst. As the latter catalyst is developed for steam reforming, testing was firstly conducted under steam reforming. Thereafter, the potential application of YST-based catalyst for autothermal reforming of heavy hydrocarbons at high temperature is explored.

\section{Experimental}

The catalysts were prepared by the modified sol-gel method, as that reported elsewhere (Lu et al. 2007). Titanium isopropoxide was dissolved in ethylene glycol. The solution was diluted by ethanol and heated at $70-80{ }^{\circ} \mathrm{C}$ while constantly stirring using magnetic stirrer. Solution became clear after some time. Citric acid was slowly added as complexing agent. Strontium nitrate, yttrium nitrate and catalytically active metal nitrates were separately dissolved in water. Aqueous metal nitrate solution was then added to the titanium isopropoxide solution. Ammonia was used to adjust $\mathrm{pH}$ to $6-7$. Solution was left overnight until a gel is formed. The gel was dried in the oven for several hours. The resulting dried gel was crushed using mortar and pestle, transferred to a crucible and heated in a furnace to $600{ }^{\circ} \mathrm{C}$ for $1 \mathrm{~h}$ to remove organic substances. The resulting powder was mixed again in a mortar and calcined at
$800{ }^{\circ} \mathrm{C}$ for $5 \mathrm{~h}$ and later at $600{ }^{\circ} \mathrm{C}$ for $10 \mathrm{~h}$ before cooling to room temperature. The resulting powder was characterized using X-ray diffraction (XRD) and surface area (BET) analysis methods. Samples phase analysis was carried out using powder X-ray diffraction with D8 advance diffractometer equipped with Ni-filtered $\mathrm{Cu} \mathrm{K} \alpha$ radiation supplied from Bruker. The specific surface area was measured using surface area and porosimetry analyser supplied from Micromeritics, model ASAP2020. The samples were degassed at $120{ }^{\circ} \mathrm{C}$ overnight before the measurements. The total surface areas were estimated using the BET equation over a range of $0.05-0.3$. Particle size was measured using transmission electron microscopy (TEM) supplied by JOEL, model JEM 1400.

The schematic diagram of the activity testing reactor is given in Fig. 1. Three gas lines are available for feeding nitrogen, hydrogen and air/oxygen. Water and liquid fuel are fed through two separate lines through two HPLC pumps. All lines lead to an oven and finally to the reactor furnace. The oven allows uniform adiabatic heating up to $200{ }^{\circ} \mathrm{C}$. Coil mixers are installed in every line for mixing. Additional coil mixers are also integrated after water and fuel are met together and thereafter such that all reactants are thoroughly mixed and heated before entering the reactor. Once introduced in the three-zone furnace the reactants mix in the SiC-filled top zone. The SiC particles helped ensuring uniform mixing and heating. After being mixed, the reactants pass through a vacant zone up to the catalyst to ensure immediate exposure to catalyst, thus avoiding pre-ignition of fuel at intermediate temperatures. The catalyst is loaded in the middle zone of the tube. The sample is pelletized, crushed and sieved through to get granules having size in the range of $0.2-0.5 \mathrm{~mm}$. The appropriate amount (in this case $0.5 \mathrm{~g}$ ) is diluted with $\mathrm{SiC}$ particles such that the total volume of the mixture is $3 \mathrm{ml}$. Once the reformates exit the furnace, they are directed to an online gas chromatographer (GC) for gas analysis.

The gas analysis is carried out on a gas chromatograph (GC) supplied by Agilent, model 7890A. The GC is equipped with three columns, one of them is molsieve (HPPlot 5A) and the two others are general-purpose columns (PlotQ, HP-1). Two detectors are integrated: thermal conductivity (TCD) and flame ionization (FID) detectors. The carrier gas used was argon. The method used is a modified version of that reported elsewhere (Thormann et al. 2008). The first column (PlotQ) is opened $2 \mathrm{~min}$ after sample injection and left open for $10 \mathrm{~min}$. The oven temperature was hold at $60^{\circ}$ for the first $12 \mathrm{~min}$ and subsequently increased to $180^{\circ}$ at a rate of $10 \mathrm{~K} / \mathrm{min}$. The latter temperature profile is necessary for the least volatile compounds (high-C compounds) to evaporate and for having sufficient resolution of the different reaction products elution times. A fast cooling rate of $50 \mathrm{~K} / \mathrm{min}$ back to $60^{\circ}$ is 
Fig. 1 Schematic diagram of a benchtop microreactor. Three gas lines with integrated coil mixers met together. Gas mixture is further mixed in an additional coil mixer. Two HPLC pumps feed water and fuel through two separate lines. These liquid lines also include individual coil mixers. After liquids are met, they are also mixed through coil mixer, and all reactants are further mixed before entering reactor tube. After reactants are introduced to the reactor furnace, they are exposed to the catalyst in the middle of the reactor tube. After reaction products exit the furnace, the heavy liquids are trapped in a chiller and gas products are directed to a gas chromatographer for gas analysis

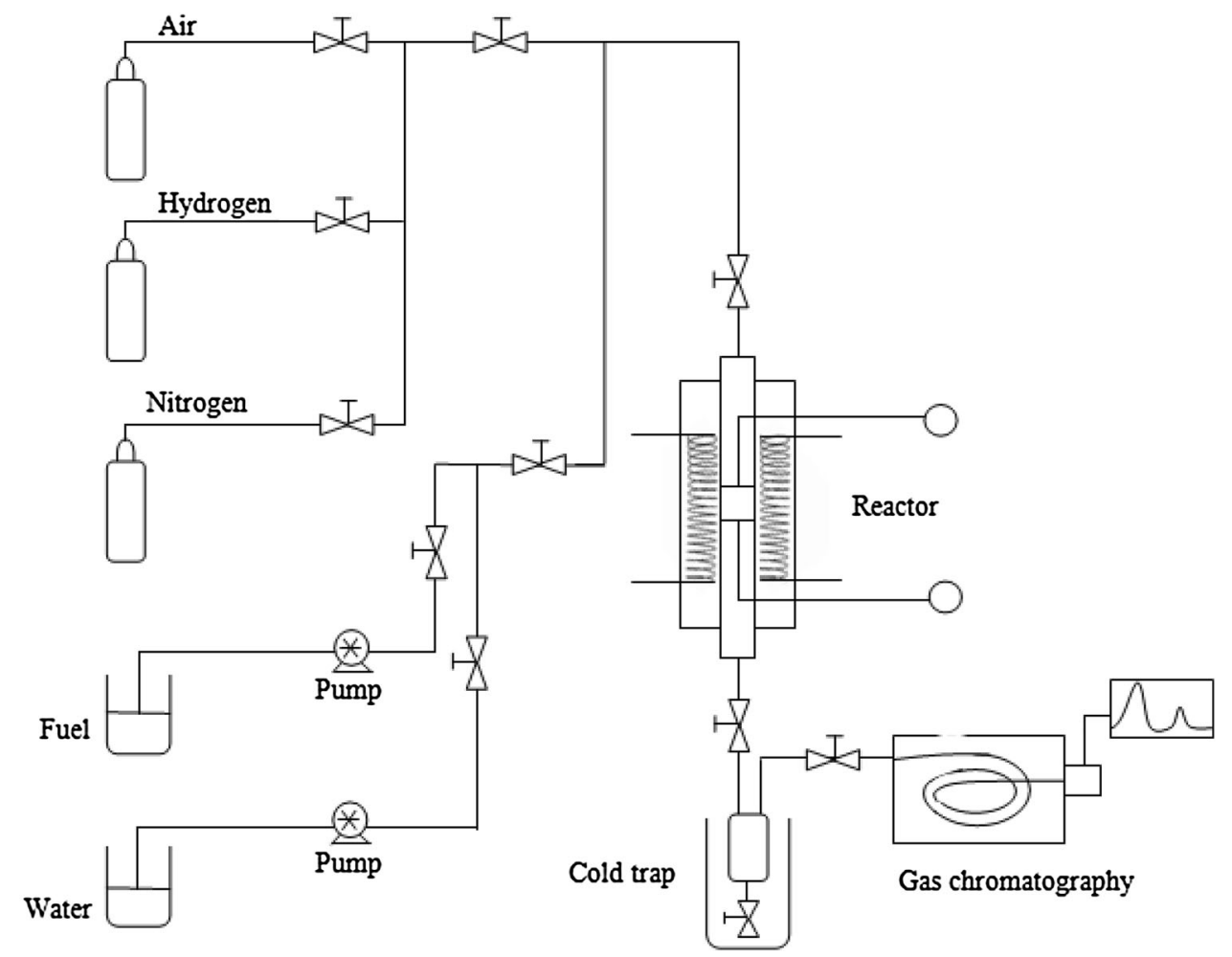

applied immediately after the high temperature $\left(180^{\circ}\right)$ is reached. The molsieve column is then opened so that the permanent gases are trapped. Nitrogen is fed in the reactor as a carrier gas and as balancing flow to determine the volume of the different reformates at GC.

\section{Results and discussion}

The materials used for the reforming catalytic reaction are: $\mathrm{Y}_{0.08} \mathrm{Sr}_{0.88} \mathrm{Ti}_{0.9} \mathrm{M}_{0.1} \mathrm{O}_{3}$, where $\mathrm{M}=\mathrm{Ni}$, Ru and Co. These materials will be subsequently designated as YSTM, where $\mathrm{M}=\mathrm{N}, \mathrm{R}$ and $\mathrm{C}$ stands for nickel, ruthenium and cobalt, respectively. The A-site deficiency is intended to enhance the ionic conductivity and yttrium at the concentration reported in this study provides the highest ionic conductivity (Fergus 2006). The doping elements on the B-site are meant to boost the catalytic activity of the catalysts. Nickel is used as it has proven to be an excellent transition metal for reforming at high temperature. Ruthenium has been chosen to represent the family of precious metals. The latter choice is the cheapest among many other precious metals such as platinum and rhodium. Cobalt was picked as it has been reported that it has superior activity than nickel yet not as expensive as ruthenium (Llorca et al. 2004; Song and Ozkan 2009; Urasaki et al. 2008; Virginie et al. 2008; Casanovas et al. 2008; de la Peña O'Shea et al. 2008). The reaction has been conducted at high temperatures within the recommended range of $700-900{ }^{\circ} \mathrm{C}$. Upper range of $800-850{ }^{\circ} \mathrm{C}$ was chosen as the conductivity increases with increasing temperature. High-temperature $\left(900{ }^{\circ} \mathrm{C}\right)$ evaluation was avoided as it is not practical commercially due to the limitations and constraints in cost, design and energy supply. The traditional Ni-alumina catalyst has been chosen as the benchmarking catalyst. As it is mainly developed for steam reforming, steam reforming was conducted on all catalysts at $T=800{ }^{\circ} \mathrm{C}$ to have a meaningful comparison. Autothermal reforming has also been conducted as it has the advantage of design simplicity, compactness and least energy requirement thus mostly celebrated commercially.

Upon preparation of the catalysts, characterizations have been conducted on the fresh catalyst including X-ray diffraction, specific surface area and transmission electron microscopy. The catalyst precursor has been calcined for $10 \mathrm{~h}$ at different temperatures of $600,650,700$ and $800{ }^{\circ} \mathrm{C}$ to study the effect of calcination temperature on the catalyst structure. Figure 2 shows a typical XRD pattern of YSTN catalyst. It is shown that low crystallinity is formed at $600{ }^{\circ} \mathrm{C}$. At $650{ }^{\circ} \mathrm{C}$ well-defined peaks are formed along with the presence of an unknown second phase. The second phase formation persisted at higher calcination temperature of $700{ }^{\circ} \mathrm{C}$ and disappeared at $800{ }^{\circ} \mathrm{C}$. As such we choose the starting calcination temperature of $800{ }^{\circ} \mathrm{C}$, but for only $5 \mathrm{~h}$, a second calcination at $600{ }^{\circ} \mathrm{C}$ for $10 \mathrm{~h}$ is conducted before furnace cooling to room temperature. It was preferred not to hold the temperature for longer time at $800{ }^{\circ} \mathrm{C}$ 


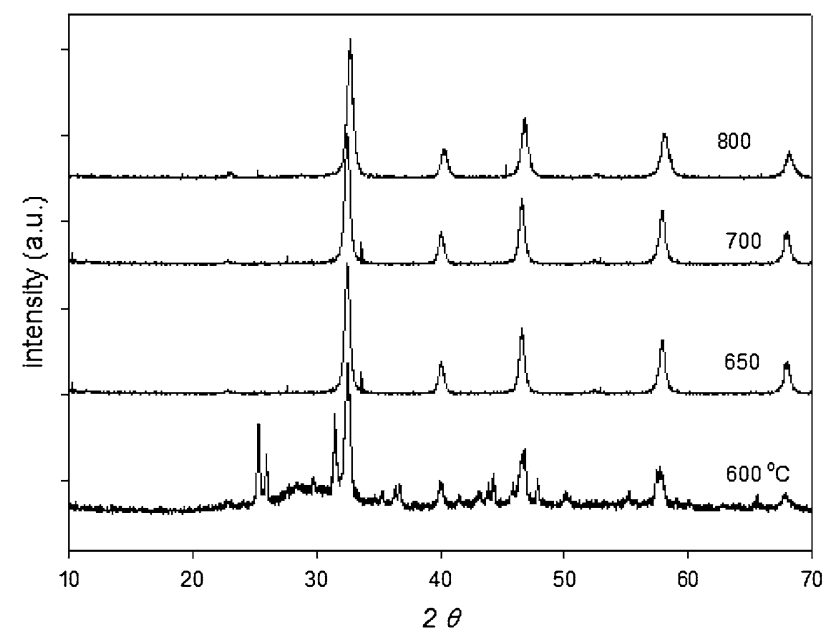

Fig. 2 XRD pattern for YSTN after calcination for $10 \mathrm{~h}$ at 600,650 , $700,800{ }^{\circ} \mathrm{C}$. Amorphous phase is clearly observed for calcination temperature of $600{ }^{\circ} \mathrm{C}$. Tiny second phase is present for calcination temperature of 650 and $700{ }^{\circ} \mathrm{C}$ and disappear at $800{ }^{\circ} \mathrm{C}$

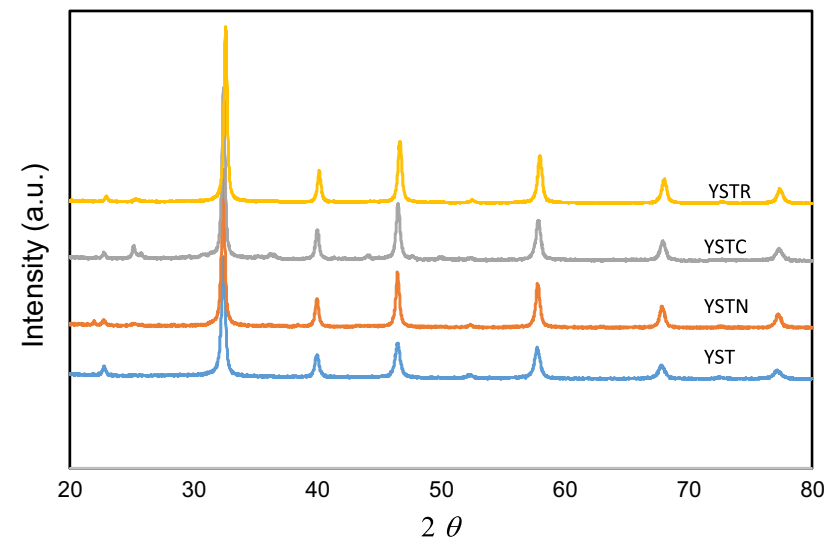

Fig. 3 XRD pattern for the different catalysts (YST, YSTC, YSTN and YSTR) after calcination at $800{ }^{\circ} \mathrm{C}$ for $5 \mathrm{~h}$ followed by dwelling at $600{ }^{\circ} \mathrm{C}$ for $10 \mathrm{~h}$. The XRD patterns showed single phase for all catalysts

to avoid coarsening and reduction in specific surface area. The same calcination profile was adopted for all catalysts. The XRD patterns are shown in Fig. 3 for the different catalysts. As shown all catalysts showed single-phase crystallinity. The specific surface area was measured to be between 10 and $20 \mathrm{~m}^{2} / \mathrm{g}$. The particles are very fine and nanoscale in size as shown in Fig. 4a for a TEM micrograph. A small highlighted portion is further shown in Fig. $4 \mathrm{~b}$ at higher magnification. Even though particles are nanoscale in size, the catalyst showed only modest specific surface area.

Activity of the catalysts was evaluated for steam and autothermal reforming of heavy hydrocarbon oil namely dodecane, a diesel surrogate free of aromatics and sulfur. Very high LHSV $=5$ was chosen in the hope of distinguishing the best-performing catalysts from the less

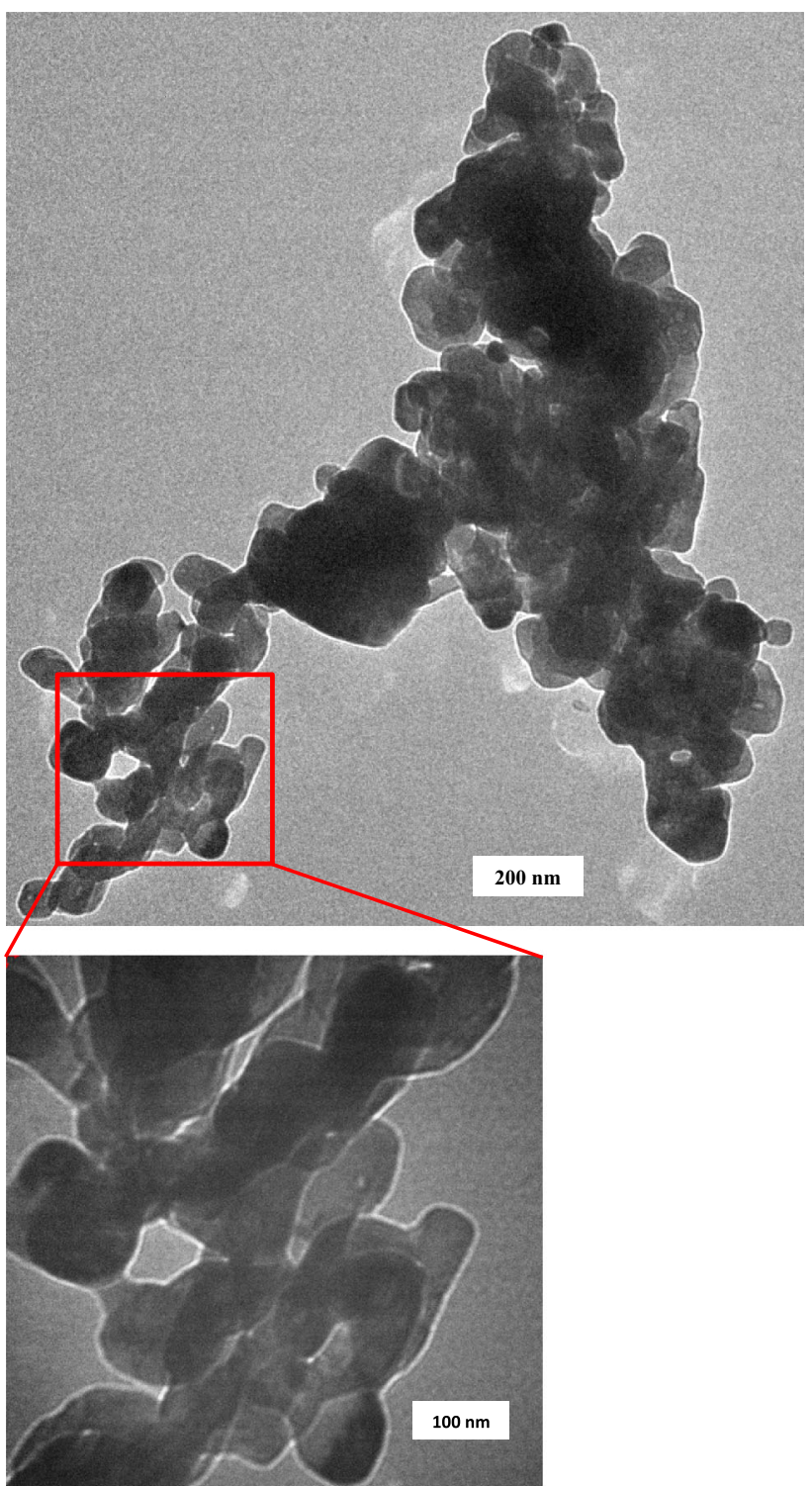

Fig. 4 a TEM micrograph of a typical fresh catalyst (YSTC). b Particle morphology at higher magnification

performing ones. Only $0.5 \mathrm{~g}$ of catalyst diluted by $\mathrm{SiC}$ particles is loaded in the middle zone of the reactor tube. $\mathrm{SiC}$ particles are also used to fill the first zone of the reactor tube to help further mixing fuel with air and water and provide uniform heating of the mixture to intermediate temperature. The reaction temperature was $800{ }^{\circ} \mathrm{C}$, while the GHSV was maintained at $22,000 \mathrm{~h}^{-1}$. Steam reforming was conducted on YST material systems and $\mathrm{Ni}$-alumina catalysts with $\mathrm{S} / \mathrm{C}=3$. Typical gas analysis data are given in Table 1 . The product gas concentrations on dry basis and free of nitrogen are shown in Fig. 5a-d and average values are listed in Table 2. The results are surprisingly very similar despite the high LHSV with the perovskite catalysts performing as well as the $\mathrm{Ni}$-alumina commercial catalyst. 
Table 1 Typical gas analysis data including compound type, retention time, area and normalized concentrations

\begin{tabular}{llcl}
\hline Compound & Retention time & Area & Concentration \\
\hline $\mathrm{CO}_{2}$ & 12.884 & 418.48 & 12.74 \\
$\mathrm{H}_{2}$ & 31.61 & 7879.72 & 47.27 \\
$\mathrm{~N}_{2}$ & 32.928 & 786.606 & 30.55 \\
$\mathrm{CH}_{4}$ & 34.3 & 1165.82 & 0.59 \\
$\mathrm{CO}$ & 36.89 & 210.39 & 8.86 \\
\hline
\end{tabular}

The hydrogen concentrations are $70 \%$ or higher for the different catalysts which is within expectation. What is, however, noticeable is the high methane concentration for YSTC catalyst. This indicates that the catalyst is not as effective reforming catalyst as more methane is slipping from catalytic reforming reaction. It is not surprising that $\mathrm{CO}_{2}$ concentration is as low as $10-11 \%$. This is in agreement with thermodynamic calculations that suggest reduction in $\mathrm{CO}_{2}$ concentrations with increasing temperature and $\mathrm{S} / \mathrm{C}$ ratio and reducing reactor pressure (Twigg 1989). In our case, reactor pressure is 2.5 bar and reaction temperature and $\mathrm{S} / \mathrm{C}$ ratio are high $\left(T=800{ }^{\circ} \mathrm{C}\right.$ and $\mathrm{S} / \mathrm{C}=3$ ). Carbon monoxide concentration is consistently higher than that of $\mathrm{CO}_{2}$ and is around $15 \%$ for Ni-alumina and YSTR and higher than $18 \%$ for YSTN and YSTC. High concentration of $\mathrm{CO}$ is favorable as $\mathrm{CO}$ can be a further source of hydrogen through water gas shift reaction that can be conducted downstream at low temperature.

The gas product concentrations listed in Table 2 are for dry basis and free of nitrogen. A better way of understanding catalyst performance could be obtained from the hydrogen yield calculated as the ratio of $\mathrm{H}_{2}$ mol to moles of input fuel which is given in Fig. 6. Carbon monoxide yield is also important in view of the fact that it can be converted back to $\mathrm{H}_{2}$ through water gas shift reaction. As such, Fig. 6 also shows $\mathrm{CO}$ yield appended to $\mathrm{H}_{2}$ yield.

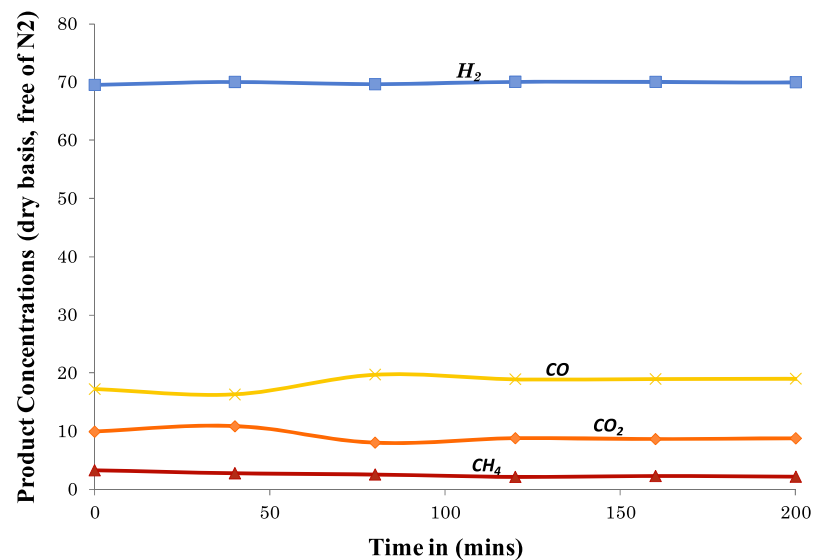

(a) YSTC

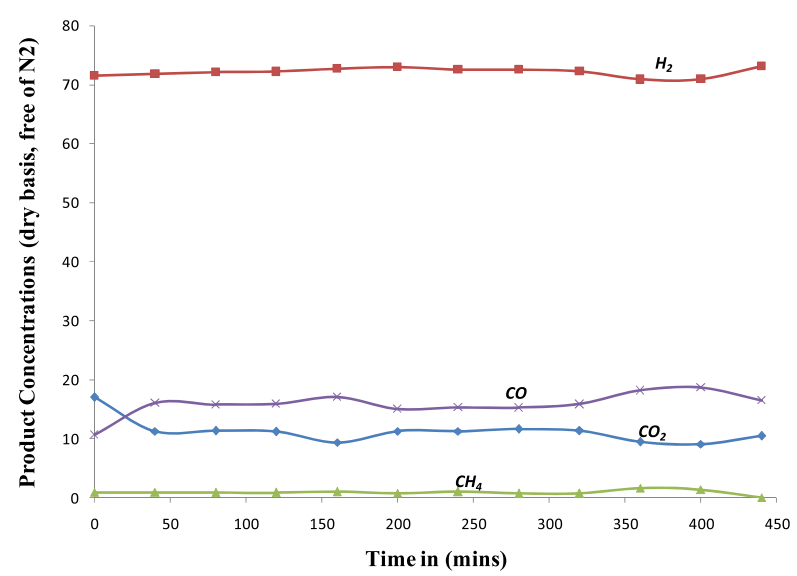

(c) YSTR

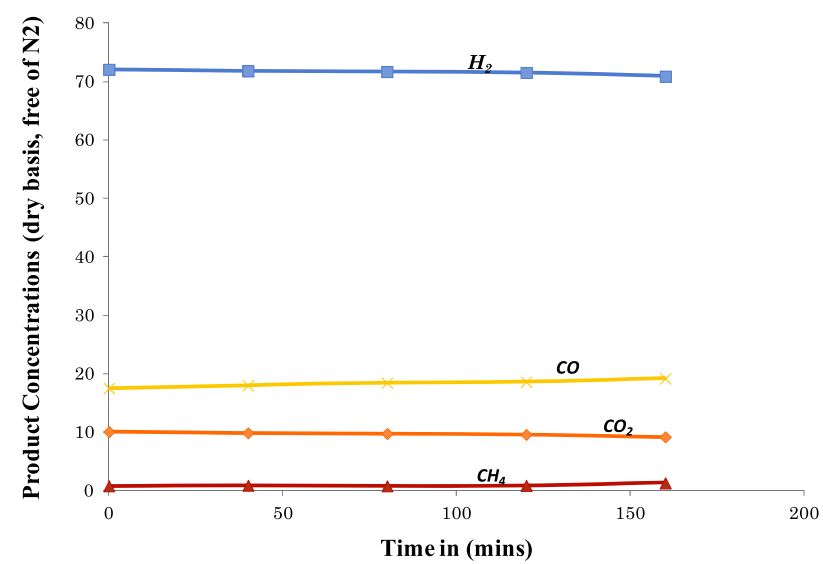

(b) YSTN

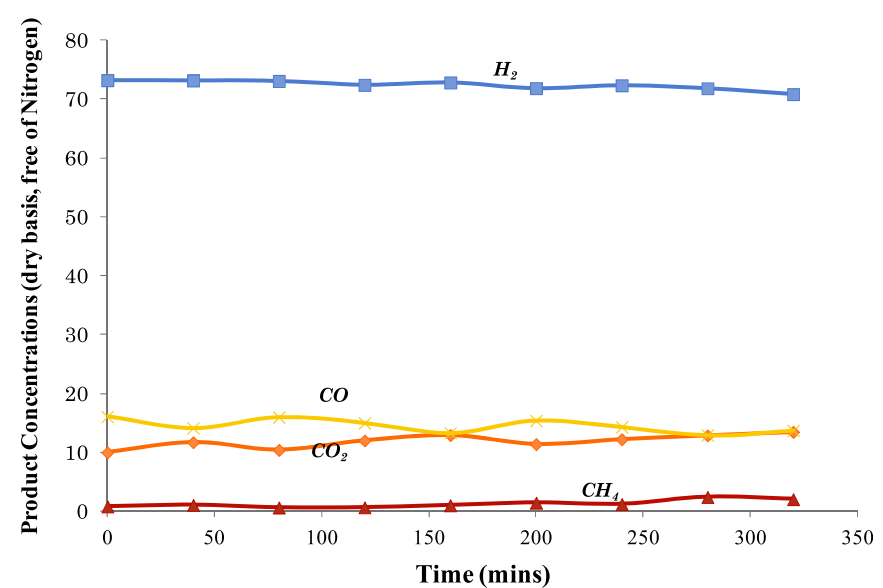

(d) Ni-Alumina

Fig. 5 Gas product $\left(\mathrm{CH}_{4}, \mathrm{CO}, \mathrm{CO}_{2}\right.$ and $\left.\mathrm{H}_{2}\right)$ concentrations for steam reforming at $800{ }^{\circ} \mathrm{C}$ and $\mathrm{S} / \mathrm{C}=3$ for a YSTN, b YSTN, c YSTR and d Nialumina 
Table 2 Conversion and gas product distribution for the different inhouse (YSTR, YSTN, YSTC) and commercial (Ni-alumina) catalysts under steam reforming at $800{ }^{\circ} \mathrm{C}$ and $\mathrm{S} / \mathrm{C}=3$

\begin{tabular}{lcccc}
\hline & YSTN & YSTC & YSTR & Ni-alumina \\
\hline $\mathrm{H}_{2}$ & 71.6 & 70 & 72.3 & 72.3 \\
$\mathrm{CO}$ & 18.4 & 18.6 & 15.2 & 14.5 \\
$\mathrm{CO}_{2}$ & 9.7 & 9 & 11.7 & 11.8 \\
$\mathrm{CH}_{4}$ & 0.95 & 2.5 & 0.82 & 1.24 \\
Conversion & 84 & 86 & 89.5 & 89.2 \\
\hline
\end{tabular}

Table 3 lists the hydrogen, $\mathrm{CO}$ and syngas $\left(\mathrm{H}_{2}+\mathrm{CO}\right)$ yields. Figures 5, 6 and Tables 2, 3 suggest that reforming dodecane with YSTR resulted in very low methane slip, highest hydrogen yield and concentration and best syngas yield that has even outperformed the commercial $\mathrm{Ni}$-alumina catalyst. Activity of the catalysts follows the order YSTR $>$ YSTN > YSTC.

Conversion or carbon balance is calculated as:

Conversion $=\frac{\Sigma \text { moles of } \mathrm{C} \text { in reformate }}{\text { Total mole of } \mathrm{C} \text { in feed }} \times 100$

Conversions are also listed in Table 3. The latter quantity is $90 \%$ for Ni-alumina and YSTR and around $85 \%$ for YSTN and YSTC. Failing to have full conversion may be due to the non-uniformity in mixing, the precombustion of fuel and the hot-spot formation due to the

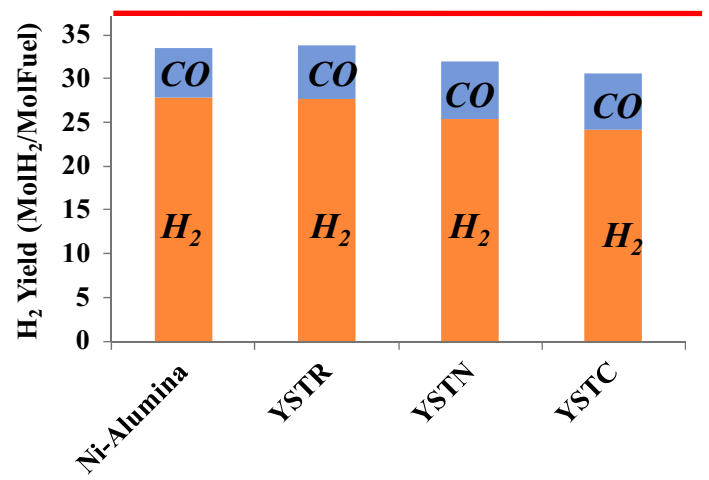

Fig. $6 \mathrm{H}_{2}$ and syngas $\left(\mathrm{H}_{2}\right.$ and $\left.\mathrm{CO}\right)$ yield for the different catalysts under steam reforming of dodecane at $T=800{ }^{\circ} \mathrm{C}, \mathrm{S} / \mathrm{C}=3$. Upper theoretical limit for $\mathrm{H}_{2}$ and syngas yield is also illustrated as a horizontal line

Table $3 \mathrm{H}_{2}, \mathrm{CO}$ and syngas yields for the different in-house (YSTR, YSTN, YSTC) and commercial (Ni-alumina) catalysts under steam reforming. ( $\left.\mathrm{S} / \mathrm{C}=3, T=800{ }^{\circ} \mathrm{C}\right)$

\begin{tabular}{lllll}
\hline & $\mathrm{H}_{2}$ Yield & CO yield & Syngas yield & Conversion \\
\hline Ni-alumina & 27.88 & 5.62 & 33.5 & 87 \\
YSTR & 27.72 & 6.06 & 33.78 & 90 \\
YSTN & 25.45 & 6.55 & 32 & 84 \\
YSTC & 24.12 & 6.48 & 30.6 & 86 \\
\hline
\end{tabular}

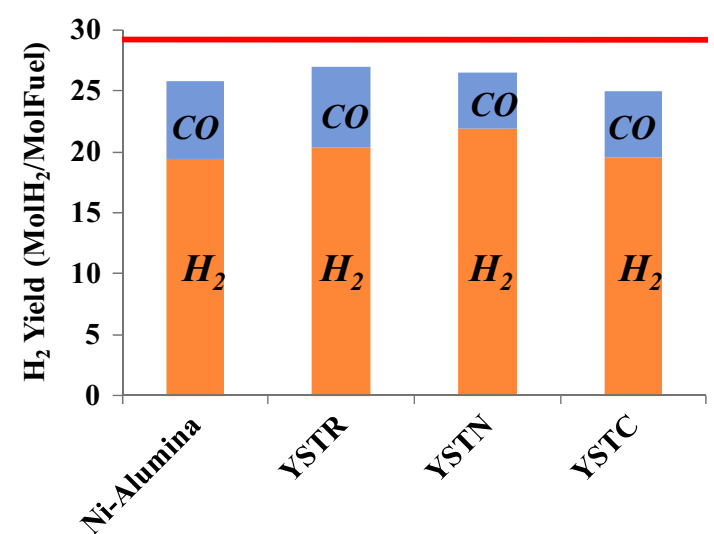

Fig. $7 \mathrm{H}_{2}$ and syngas $\left(\mathrm{H}_{2}\right.$ and $\left.\mathrm{CO}\right)$ yield for the different catalysts under autothermal reforming of dodecane at $T=800{ }^{\circ} \mathrm{C}, \mathrm{S} / \mathrm{C}=3$ and $\mathrm{O} / \mathrm{C}=0.32$. Upper theoretical limit for $\mathrm{H}_{2}$ and syngas yield is also illustrated as a horizontal line

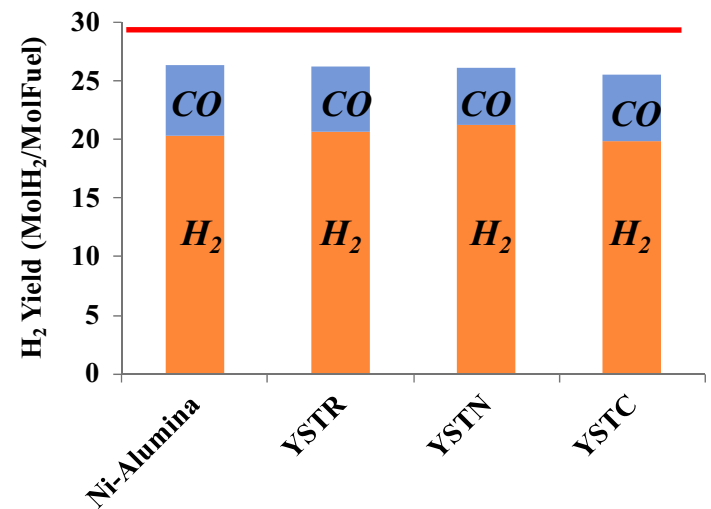

Fig. $8 \mathrm{H}_{2}$ and syngas $\left(\mathrm{H}_{2}\right.$ and $\left.\mathrm{CO}\right)$ yield for the different catalysts under autothermal reforming of dodecane at $T=850{ }^{\circ} \mathrm{C}, \mathrm{S} / \mathrm{C}=3$ and $\mathrm{O} / \mathrm{C}=0.32$. Upper theoretical limit for $\mathrm{H}_{2}$ and syngas yield is also illustrated as a horizontal line

non-uniform temperature distribution and inhomogeneous fuel mixing.

The steam reforming reaction is given by:

$\mathrm{C}_{n} \mathrm{H}_{m}+n \mathrm{H}_{2} \mathrm{O} \rightarrow n \mathrm{CO}_{x}+(n+m / 2) \mathrm{H}_{2} \quad \Delta \mathrm{Hr}>0$

Assuming that dodecane is $100 \%$ converted and no CO is produced, the reaction would become:

$\mathrm{C}_{12} \mathrm{H}_{26}+36 \mathrm{H}_{2} \mathrm{O} \rightarrow 12 \mathrm{CO}_{2}+37 \mathrm{H}_{2}+12 \mathrm{H}_{2} \mathrm{O}$

That is, theoretically the $\mathrm{H}_{2}$ yield is 37 . A line at $\mathrm{H}_{2} /$ fuel mole ratio $=37$ is also constructed in Fig. 6 to define the theoretical limit for $\mathrm{H}_{2}$ yield. This theoretical limit is also valid for syngas production as $\mathrm{CO}$ is absent in the products of reaction (2). As such, both Ni-alumina and YSTR catalysts are of more than $90 \%$ of the theoretical limit.

Current focus is more on autothermal reforming not only because of cost reasons but also because ATR favors design compactness and simplicity and also better thermal 
Table 4 Conversion and $\mathrm{H}_{2}, \mathrm{CO}$ and syngas yields for the different in-house (YSTR, YSTN, YSTC) and commercial (Ni-alumina) catalysts under autothermal reforming. $\left(\mathrm{S} / \mathrm{C}=3, \mathrm{O} / \mathrm{C}=0.32, T=800,850{ }^{\circ} \mathrm{C}\right)$

\begin{tabular}{|c|c|c|c|c|c|c|c|c|}
\hline & \multicolumn{2}{|l|}{$\mathrm{H}_{2}$ yield } & \multicolumn{2}{|l|}{ CO yield } & \multicolumn{2}{|l|}{ Syngas yield } & \multicolumn{2}{|c|}{$\%$ Conversion } \\
\hline & $T=800^{\circ} \mathrm{C}$ & $T=850^{\circ} \mathrm{C}$ & $T=800^{\circ} \mathrm{C}$ & $T=850^{\circ} \mathrm{C}$ & $T=800^{\circ} \mathrm{C}$ & $T=850^{\circ} \mathrm{C}$ & $T=800{ }^{\circ} \mathrm{C}$ & $T=850^{\circ} \mathrm{C}$ \\
\hline $\mathrm{Ni}$-alumina & 19.4 & 20.4 & 6.3 & 6 & 25.7 & 26.4 & 86 & 86.8 \\
\hline YSTR & 20.4 & 20.8 & 6.5 & 5.6 & 27 & 26.4 & 88.8 & 84.5 \\
\hline YSTN & 21.9 & 21.3 & 4.6 & 4.9 & 26.5 & 26.2 & 87.2 & 86 \\
\hline YSTC & 19.5 & 19.9 & 5.5 & 5.8 & 25 & 25.7 & 85.5 & 84.7 \\
\hline
\end{tabular}

efficiency. Autothermal reforming activity at $\mathrm{S} / \mathrm{C}=3$ and $\mathrm{O} / \mathrm{C}=0.32$ and at two temperatures 800 and $850{ }^{\circ} \mathrm{C}$ are given in Figs. 7, 8 and in Table 4. Again the results are similar and quite comparable with the commercial catalyst. The latter is mainly developed for methane steam reforming; however, it performed quite well for ATR and under heavy hydrocarbon, namely dodecane. It is interesting to note that the perovskite catalyst has nearly the same performance as $\mathrm{Ni}$-alumina catalyst irrespective of the doping element. However, YSTN and YSTR are consistently slightly better than YSTC and do sometimes over perform Ni-alumina catalyst although by slight amount.

The autothermal reforming reaction is given by:

$$
\mathrm{C}_{n} \mathrm{H}_{m}+\mathrm{O}_{2}+n \mathrm{H}_{2} \mathrm{O} \rightarrow n \mathrm{CO}_{x}+(n+m / 2) \mathrm{H}_{2} \quad \Delta \mathrm{Hr} \cong 0
$$

The reaction assuming that the entire carbon monoxide is converted into $\mathrm{CO}_{2}$ through the water gas shift reaction, would be

$$
\begin{aligned}
\mathrm{C}_{12} \mathrm{H}_{26}+36 \mathrm{H}_{2} \mathrm{O}+3.78 \mathrm{O}_{2} \rightarrow & 12 \mathrm{CO}_{2}+29.5 \mathrm{H}_{2} \\
& +19.5 \mathrm{H}_{2} \mathrm{O}
\end{aligned}
$$

The highest theoretical hydrogen yield is 29.5 and is given in both Figs. 7 and 8 as a horizontal upper limit for syngas yield. The syngas yield for all in-house prepared catalysts is nearly $90 \%$ of the theoretical limit with YSTR having highest value.

Overall the performance of the catalysts is nearly the same for both temperatures $\left(800\right.$ and $\left.850{ }^{\circ} \mathrm{C}\right)$. Improvement in activity is not noticed with increasing temperature as predicted by thermodynamics. This was mainly due to the problem with the equipment design, lacking a separate preheater due to space limitation. As reaction temperature is increased, the top (mixing/preheating) zone temperature is also increased above the set value, and thus pre-combustion and inhomogeneous mixing are more pronounced at $850{ }^{\circ} \mathrm{C}$. This is also reflected by the slight lower conversion at $850{ }^{\circ} \mathrm{C}$ as compared with that at $800{ }^{\circ} \mathrm{C}$. Overall the YST-based catalysts are promising for autothermal reforming of dodecane with $\mathrm{Ru}$ the best active dopant, followed by $\mathrm{Ni}$ and lastly by $\mathrm{Co}$. As dodecane is one of the main diesel surrogates, the testing of the catalyst for diesel reforming may also show promising performance. Such analysis is left for future activity.

\section{Conclusion}

YST-based perovskite catalysts were prepared and characterized for structural properties. Single-phase crystallinity and specific surface area between 10 and $20 \mathrm{~m}^{2} / \mathrm{g}$ were measured, and the particles were nanoscale in size. The activity was tested at two temperatures $800,850{ }^{\circ} \mathrm{C}$ and under both steam and autothermal reforming. Three types of doping on B-site gave very similar activity, conversion and hydrogen and syngas yields that were quite comparable with those of commercial catalyst. Over the period of $12-24 \mathrm{~h}$, the catalysts were stable and no degradation was noticed. Such degradation may potentially emerge upon adding sulfur to fuel. Such analysis is undergoing and will be reported in the future. The high activity and stability of these catalysts doped with precious or transitional cost-effective metals provide a potential alternative family of reforming catalysts for commercial transportation fuel in an onboard reformer.

Acknowledgments This project was funded by the National Plan for Science, Technology and Innovation (MAARIFAH)-King Abdulaziz City for Science and Technology - the Kingdom of Saudi Arabia, award number 09-ENE807-05.

Open Access This article is distributed under the terms of the Creative Commons Attribution 4.0 International License (http:// creativecommons.org/licenses/by/4.0/), which permits unrestricted use, distribution, and reproduction in any medium, provided you give appropriate credit to the original author(s) and the source, provide a link to the Creative Commons license, and indicate if changes were made.

\section{References}

Ayabe S, Omoto H, Utaka T, Kikuchi R (2003) Catalytic autothermal reforming of methane and propane over supported metal catalysts. Appl Catal A 241:261 
Casanovas A, de Leitenburg C, Trovarelli A, Llorca J (2008) Catalytic monolith for ethanol steam reforming. Catal Today 138:187-192

Chen HW, Wang CY, Yu CH, Tseng LT, Liao PH (2004) Carbon dioxide reforming of methane reaction catalyzed by stable nickel copper catalysts. Catal Today 97:173-180

de la Peña O'Shea VA, Nafria R, de la Piscina PR, Homs N (2008) Development of robust Co-based catalysts for the selective $\mathrm{H}_{2}-$ production by ethanol steam-reforming. The Fe-promoter effect. Int J Hydrogen Energy 33:3601-3606

Descorme C, Madier Y, Duprez D, Birchem T (2000) Studies in surface science and catalysis. In: A. Corma, F.V. Melo, S. Mendioroz, J.L.G. Fierro (Eds.), 12th International congress on catalysis. Elsevier Science. 130: 347

Dias JAC, Assaf JM (2003) Influence of calcium content in $\mathrm{Ni} / \mathrm{CaO} /-$ $\mathrm{Al}_{2} \mathrm{O}_{3}$ catalysts for $\mathrm{CO}_{2}$-reforming of methane. Catal Today 85:59-68

Dinka P, Mukasyan AS (2007) Perovskite catalysts for the autoreforming of sulfur containing fuels. J Power Sour 167:472-481

Erria P, Dinka P, Varma A (2006) Novel perovskite-based catalysts for autothermal JP-8 fuel reforming. Chem Eng Sci 61:5328-5333

Fergus JW (2006) Oxide anode materials for solid oxide fuel cells. Solid State Ionics 177:1529-1541

Guo J, Lou H, Zhao H, Chai D, Zheng X (2004) Dry reforming of methane over nickel catalysts supported on magnesium aluminate spinels. Appl Catal A Gen 273:75-82

Ho SS, Choi SH, Park ED, Han SH, Lee JS (2002) Mn-promoted Ni/ $\mathrm{Al}_{2} \mathrm{O}_{3}$ catalysts for stable carbon dioxide reforming of methane. J Catal 209:6-15

Juan-Juan J, Román-Martınez MC, Illán-Gómez MJ (2004) Catalytic activity and characterization of $\mathrm{Ni} / \mathrm{Al}_{2} \mathrm{O}_{3}$ and $\mathrm{NiK} / \mathrm{Al}_{2} \mathrm{O}_{3}$ catalysts for $\mathrm{CO}_{2}$ methane reforming. App Catal A Gen 264:169-174

Kondakindi RR, Kundu A, Karan K, Peppley BA, Qi A, Thurgood C, Schurer P (2010) Characterization and activity of perovskite catalysts for autothermal reforming of dodecane. Appl Catal A Gen 390:271-280

Lee JH, Lee EG, Joo OS, Jung KD (2004) Stabilization of $\mathrm{Ni} / \mathrm{Al}_{2} \mathrm{O}_{3}$ catalyst by $\mathrm{Cu}$ addition for $\mathrm{CO}_{2}$ reforming of methane. Appl Catal A Gen 269:1-6

Liu DJ, Krumpelt M (2005) Activity and structure of perovskite as diesel reforming catalysts for solid oxide fuel cell. Int J Appl Ceram Technol 2:301-307

Llorca J, Homs N, Sales J, Fierro JLG, de la Piscina RP (2004) Effect of sodium addition on the performance of Co-ZnO-based catalysts for hydrogen production from bioethanol. J Catal 222:470-480

Lu X, Pine TS, Mumm DR, Brouwer J (2007) Modified Pechini synthesis and characterization of Y-doped strontium titanate perovskite. Solid State Ionics 178:1195-1199

Martınez R, Romero E, GuimonC Bilbao R (2004) $\mathrm{CO}_{2}$ reforming of methane over coprecipitated $\mathrm{Ni}-\mathrm{Al}$ catalysts modified with lanthanum. Appl Catal A Gen 274:139-149

Matsumura Y, Nakamori T (2004) Steam reforming of methane over nickel catalysts at low reaction temperature. Appl Catal A Gen 258:107-114
Mawdsley JR, Krause TR (2006) Rare earth-first-row transition metal perovskites as catalysts for the autothermal reforming of hydrocarbon fuels to generate hydrogen. Appl Catal A Gen 334:311-320

Mawdsley JR, Krause TR (2008) Rare earth-first-raw transition metal perovskite as catalysts for the autothermal reforming of hydrocarbon fuels to generate hydrogen. Appl Catal A Gen 334:311-320

Mota N, Alvarez-Galván MC, Navarro RM, Al-Zahrani SM, Goguet A, Daly H, Zhang W, Trunschke A, Schlögl R, Fierro JLG (2012) Insights on the role of Ru substitution in the properties of $\mathrm{LaCoO}_{3}$-based oxides as catalysts precursors for the oxidative reforming of diesel fuel. Appl Catal B 113-114:271-280

Navarro RM, Alvarez-Galvan MC, Villoria JA, Gonzalez-Jimenez LD, Rosa F, Fierro JLG (2007) Effect of $\mathrm{Ru}$ on $\mathrm{LaCoO}_{3}$ perovskite-derived catalyst properties in oxidative reforming of diesel. Appl Catal B Environ 73:247-258

Nimwattanakul W, Luengnaruemitchai A, Jitkarnka S (2006) Potential of Ni supported on clinoptilolite catalysts for carbon dioxide reforming of methane. Int J Hydrogen Energy 31:93-100

Provendier H, Petit C, Kiennemann A (2001) Steam reforming of methane on $\mathrm{LaNi}_{\mathrm{x}} \mathrm{Fe}_{1-\mathrm{x}} \mathrm{O}_{3}(0 \leq \mathrm{x} \leq 1)$ perovskites. Reactivity and characterisation after test. Comptes Rendus de l'Academie des Sciences-Series IIC-Chemistry 4:57-66

Quincoces CE, Vargas SPD, Grange P, Gonzalez MG (2002) Role of Mo in $\mathrm{CO}_{2}$ reforming of $\mathrm{CH}_{4}$ over Mo promoted $\mathrm{Ni} / \mathrm{Al}_{2} \mathrm{O}_{3}$ catalysts. Mater Lett 56:698-704

Song H, Ozkan US (2009) Ethanol steam reforming over Co-based catalysts: role of oxygen mobility. J Catal 261:66-74

Thormann J, Pfeifer P, Schubert K, Kunz U (2008) Reforming of diesel in a micro reactor for APU systems. Chem Eng J 135:S74S 81

Twigg MV (1989) Catalyst handbook, 2nd edn. Wolfe publishing Ltd, London

Urasaki K, Tokunaga K, Semine Y, Matsukata M, Kikuchi E (2008) Production of hydrogen by steam reforming of ethanol over cobalt and nickel catalysts supported on perovskite-type oxides. Catal Commun 9:600-604

Villoria JA, Mota N, Al-Sayari SA, Álvarez-Galván MC, Navarro RM, Fierro JLG (2012) Perovskite as catalysts in the reforming of hydrocarbon: a review. Micro Nanosyst 4:231-252

Virginie M, Araque M, Roger AC, Vargas JC, Kiennemann A (2008) Comparative study of $\mathrm{H}_{2}$ production by ethanol steam reforming on $\mathrm{Ce}_{2} \mathrm{Zr}_{1.5} \mathrm{Co}_{0.5} \mathrm{O}_{8-\delta}$ and $\mathrm{Ce}_{2} \mathrm{Zr}_{1.5} \mathrm{Co}_{0.47} \mathrm{Rh}_{0.07} \mathrm{O}_{8-\delta}$ Evidence of the $\mathrm{Rh}$ role on the deactivation process. Catal Today 138:21-27

Wang JB, KuoL E, Huang TJ (2003) Study of carbon dioxide reforming of methane over bimetallic $\mathrm{Ni}-\mathrm{Cr} / \mathrm{yttria}$-doped ceria catalysts. Appl Catal A Gen 249:93-105

Wang L, Murata K, Inaba M (2004) Development of novel highly active and sulphur-tolerant catalysts for steam reforming of liquid hydrocarbons to produce hydrogen. Appl Catal A Gen 257:43-47

Zhang J, Wang Y, Ma R, Wu D (2003) Characterization of aluminasupported $\mathrm{Ni}$ and $\mathrm{Ni}-\mathrm{Pd}$ catalysts for partial oxidation and steam reforming of hydrocarbons. Appl Catal A Gen 243:251-259

Zhu T, Flytzani-Stephanopoulos M (2001) Catalytic partial oxidation of methane to synthesis gas over $\mathrm{Ni}-\mathrm{CeO}_{2}$. Appl Catal A Gen 208:403-417 